\title{
Journal of Management http://jom.sagepub.com/
}

\section{Breach Begets Breach: Trickle-Down Effects of Psychological Contract Breach on Customer Service}

Prashant Bordia, Simon Lloyd D. Restubog, Sarbari Bordia and Robert L. Tang Journal of Management 2010 36: 1578 originally published online 30 July 2010

DOI: $10.1177 / 0149206310378366$

The online version of this article can be found at:

http://jom.sagepub.com/content/36/6/1578

\author{
Published by: \\ (S)SAGE \\ http://www.sagepublications.com \\ On behalf of:

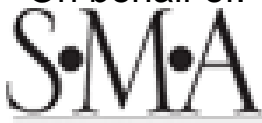 \\ SOUTHERN \\ MANAGEMENT \\ Southern Management Association
}

Additional services and information for Journal of Management can be found at:

Email Alerts: http:/jom.sagepub.com/cgi/alerts

Subscriptions: http://jom.sagepub.com/subscriptions

Reprints: http://www.sagepub.com/journalsReprints.nav

Permissions: http://www.sagepub.com/journalsPermissions.nav

Citations: http://jom.sagepub.com/content/36/6/1578.refs.html 
Journal of Management

Vol. 36 No. 6, November 2010 1578-1607

DOI: $10.1177 / 0149206310378366$

(C) The Author(s) 2010

Reprints and permission: http://www. sagepub.com/journalsPermissions.nav

\title{
Breach Begets Breach: Trickle-Down Effects of Psychological Contract Breach on Customer Service
}

\author{
Prashant Bordia \\ Simon Lloyd D. Restubog \\ Sarbari Bordia \\ The Australian National University \\ Robert L. Tang \\ De La Salle-College of Saint Benilde
}

\begin{abstract}
Adopting a multifoci approach to psychological contract breach (i.e., breach by the organization referent and breach by the supervisor referent), the authors propose a trickle-down model of breach. Results from three studies show that supervisor perceptions of organizational breach are negatively related to supervisor citizenship behaviors toward the subordinate, resulting in subordinate perceptions of supervisory breach. Subordinate breach perceptions are, in turn, negatively related to subordinate citizenship behaviors toward the customer and, ultimately, customer satisfaction. The findings demonstrate the interconnected nature of social exchange relationships at work and draw attention to the effects of breach for other employees and customers.
\end{abstract}

Keywords: psychological contract breach; customer service; social exchange theory

Acknowledgements: We are grateful to Dan Brass, Christian Kiewitz, Carol Kulik, Jaco Lok, Sara Rynes-Weller, Steven Lui, and Tom Zagenczyk for their comments on previous versions of this article.

Corresponding author: Prashant Bordia, Research School of Business, The Australian National University, LF Crisp Building 26, Canberra ACT 0200, Australia

E-mail: Prashant.Bordia@anu.edu.au

1578 
In the past decade, a great deal of research attention has been devoted to the consequences of psychological contract breach (or an employee's perception that the organization has failed to fulfill promised obligations; Conway \& Briner, 2009; Raja, Johns, \& Ntalianis, 2004; Restubog, Hornsey, Bordia, \& Esposo, 2008; Taylor \& Tekleab, 2004; Zhao, Wayne, Glibkowski, \& Bravo, 2007). A recent meta-analysis found more than 100 studies linking breach with outcomes such as lower job satisfaction, organizational commitment, in-role performance, and organizational citizenship behaviors (OCBs) and higher turnover intention and turnover (Zhao et al., 2007). The theoretical interpretation of these findings is derived from social exchange theory (Coyle-Shapiro \& Conway, 2004; Rousseau, 1995; Shore \& Tetrick, 1994). Employers and employees are engaged in a social exchange relationship: If the employers fail to fulfill their obligations, the employees respond by reducing their contributions. The range of detrimental outcomes associated with breach reinforces the importance of understanding its antecedents (or causes), nature, and consequences (Conway \& Briner, 2009; Dulac, Coyle-Shapiro, Henderson, \& Wayne, 2008).

To date, much of the research on breach has examined breach perceptions of individual employees and has focused on the employee-organization relationship, overlooking the fact that individual employees are embedded in a range of formal and informal relationships at work, including employee-supervisor, employee-team, and employee-customer relationships (Ho, 2005; Lavelle, Rupp, \& Brockner, 2007). These relationships can be mutually dependent, such that the fulfillment of obligations in one relationship may be dependent on the successful exchange of resources in another relationship (Emerson, 1976). In their classic work on social exchange networks, Cook and Emerson (1978) emphasized the need to expand the study of social exchange beyond a dyadic relationship and to consider the interdependencies in connected networks; lack of attention to these linkages has been a major limitation of existing research on social exchange in employment relationships (CoyleShapiro \& Conway, 2004).

In the research reported here, we apply recent work on the trickle-down effects of work attitudes and behaviors (Aryee, Chen, Sun, \& Debrah, 2007; Masterson, 2001; Tepper \& Taylor, 2003) to develop a model that links a supervisor's experience of psychological contract breach with the subordinate's experience of breach, ultimately resulting in poorer customer service by the subordinate (see Figure 1). In Path A in Figure 1, we propose that when supervisors experience breach of psychological contract with the organization (supervisor PCB-O), they reduce their contributions to the organization, including discretionary supervisory responsibility toward the subordinate (such as citizenship behaviors toward the subordinate; Tepper \& Taylor, 2003). This results in the subordinate perceiving a breach of psychological contract associated with the supervisor (subordinate PCB-S; Path B). The subordinate will in turn reduce discretionary effort in his or her job performance, including citizenship behaviors toward customers (Path C), and thereby undermine customer satisfaction (Podsakoff, MacKenzie, Paine, \& Bachrach, 2000), as shown in Path D in Figure 1.

Our model and accompanying empirical studies extend the literature on psychological contract breach in several ways. First, the model addresses the call for greater attention to the interdependent nature of social exchange relationships where the outcomes of one social exchange relationship (the supervisor-organization relationship) may have consequences for another (the supervisor-subordinate relationship; Coyle-Shapiro \& Conway, 2004; Emerson, 


\section{Figure 1}

\section{Model of the Trickle-Down Effects of Breach}

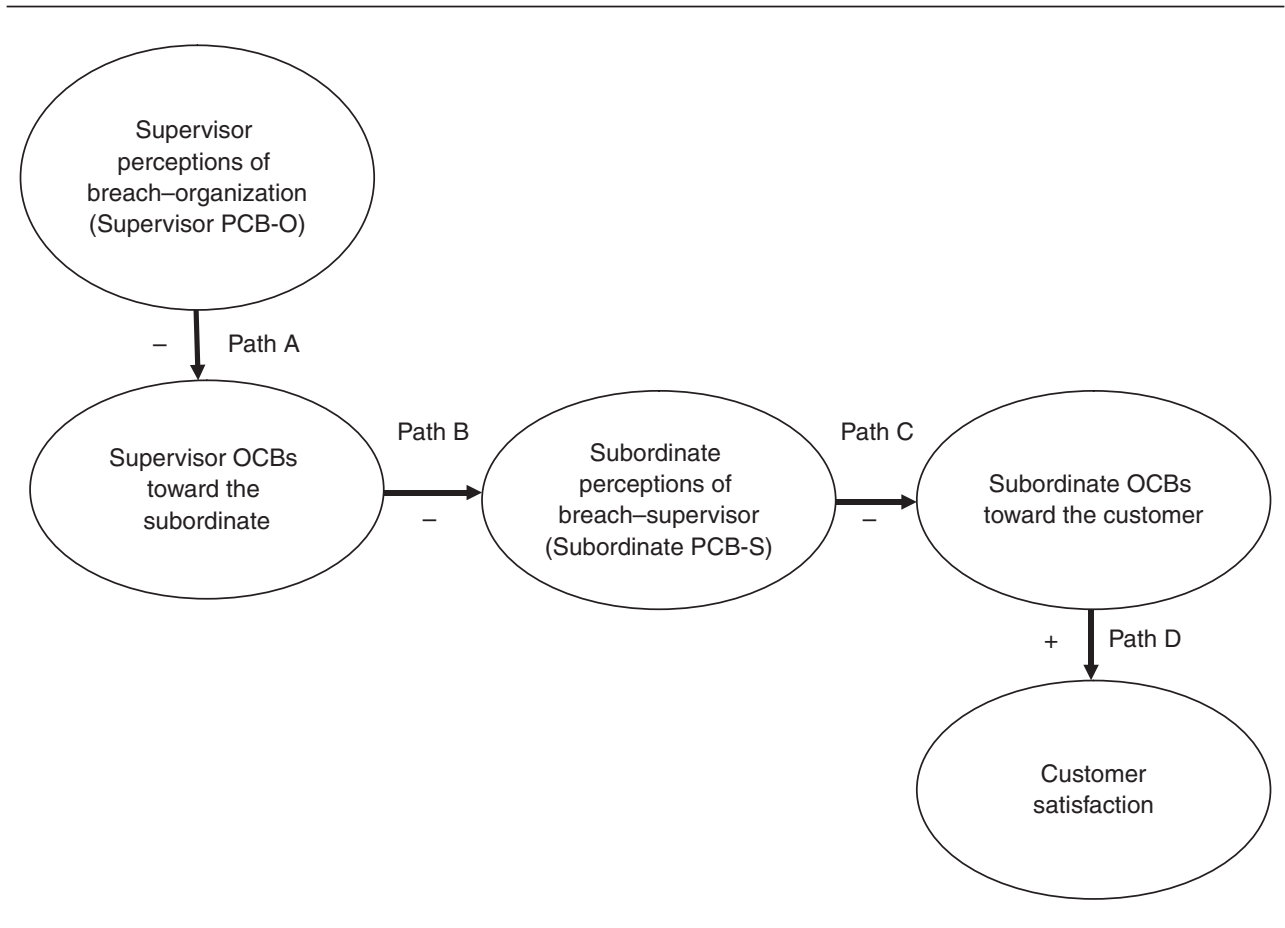

Note: $\mathrm{OCBs}=$ organizational citizenship behaviors.

1981; Shore et al., 2004). Given the interconnected nature of social exchange relationships, a breach could be "triggering off a chain of further breaches" (Coyle-Shapiro \& Conway, 2004: 24). This possibility has not been explored in previous research.

Second, previous research on the outcomes of psychological contract breach has been in relation to individual performance and job attitudes (Zhao et al., 2007). We examine the trickle-down effect of breach and thereby consider breach as an outcome of breach in organization-supervisor-subordinate relationships; thus, we expand the type of outcomes considered in psychological contract research. Moreover, although there has been a great deal of work on the outcomes of breach, there is relatively less attention devoted to its antecedents (Taylor \& Tekleab, 2004). The trickle-down approach also uncovers the role of supervisor perceptions of breach as an antecedent of subordinate perceptions of breach.

Third, employee perceptions of breach have been examined only in relation to the organization. There has been a call for greater specification of foci (organization, supervisor, or team) in social exchange relationships (Lavelle et al., 2007), and while foci have been expanded for a variety of exchange-based constructs, psychological contract breach has been studied only in relation to the organization referent (Shore et al., 2004). We adopt a 
multifoci approach to breach and propose the supervisor as an important referent in the subordinate psychological contract (Rousseau, 1995). Thus, our research addresses the call for greater attention to the role of specific agents (e.g., supervisors) in psychological contract breach (Coyle-Shapiro \& Shore, 2007; Taylor \& Tekleab, 2004). This approach allows us to study psychological contract breach using a specific dyadic relationship context (i.e., supervisorsubordinate), which is more tangible than the abstract "organization" as a party to the exchange relationship (Shore et al., 2004).

Finally, although a wide variety of outcomes have been investigated in the context of breach, the effects of breach upon employees' customer service have not been studied. A high quality of customer service is important for the success of organizations in the services sector, such as hospitality, health care, finance, and retail (Yeung \& Berman, 1997). Customer satisfaction is positively related to firm profitability, customer loyalty, positive word-ofmouth recommendations, and willingness to pay for the service (Homburg, Koschate, \& Hoyer, 2005; Szymanski \& Henard, 2001). Thus, it is not surprising that increasing research attention is being devoted to predictors of customer service behaviors. Of particular interest to management and organizational behavior scholars is the finding that the internal workings of the organization - and the resulting employee attitudes - have an effect on the quality of customer service provided by the employees (Masterson, 2001; Schneider, Ehrhart, Mayer, Saltz, \& Niles-Jolly, 2005; Schneider, Gunnarson, \& Niles-Jolly, 1994;). We aim to contribute to this research area by examining the effects of employee psychological contract breach on customer-focused citizenship behaviors and the resulting customer satisfaction.

The proposed relationships are tested in a programmatic series of three studies. These studies use a combination of multisource data, including supervisor, subordinate, and customer reports, and organizational records related to customer service commendations to subordinates. In the following sections, we review the background literature and develop theoretical justification for each path in our model.

\section{Psychological Contract Breach With Organization and Supervisor}

Psychological contract refers to the unwritten elements of the exchange relationship between an employee and the organization and includes an employee's beliefs about the organization's obligations toward him or her (Rousseau, 1995). As in other social relationships, the psychological contract is governed by the rules of social exchange and the norm of reciprocity (Conway \& Briner, 2005; Coyle-Shapiro \& Conway, 2004; Taylor \& Tekleab, 2004). When the organization is perceived as having fulfilled its obligations, the employee is more satisfied with (Robinson \& Rousseau, 1994) and committed to the organization (Restubog, Bordia, \& Tang, 2006) and reciprocates with higher job performance and better citizenship behaviors (Robinson \& Morrison, 2000; Turnley, Bolino, Lester, \& Bloodgood, 2003). When the organization fails to fulfill its obligations (Morrison \& Robinson, 1997; Rousseau, 1995) - referred to as a breach of the psychological contract by the organization (i.e., PCB-O) - employees may withhold in-role performance and OCBs (Turnley et al., 2003), exhibit withdrawal behaviors such as absenteeism (Deery, Iverson, \& Walsh, 2006), and may even act to harm organizational interests via deviant behaviors (Bordia, Restubog, \& Tang, 2008). 
We propose that a psychological contract can also underpin the social exchange relationship between an employee and his or her supervisor (Shore et al., 2004). Psychological contract theory does acknowledge that various organizational agents are responsible for the formation and fulfillment or breach of the contract, including the supervisor, senior managers, the human resources staff, and recruiting agents (Rousseau, 1995, 1998; Rousseau \& Greller, 1994; Shore \& Tetrick, 1994). Of these agents, the supervisor is considered the most salient referent in the employee's contract (Chen, Tsui, \& Zhong, 2008; Coyle-Shapiro \& Shore, 2007; Dabos \& Rousseau, 2004). However, to our knowledge, the role of the psychological contract in the supervisor-subordinate relationship has not been examined.

In contrast, several other areas of research have recognized the multiple foci that operate in social exchange-based relationships in the workplace, including the supervisor, coworkers, work teams, organization, and customers (Cropanzano \& Rupp, 2008; Lavelle et al., 2007). For example, research on perceptions of support in the workplace distinguishes between perceived organizational support and perceived supervisor support (Eisenberger, Stinglhamber, Vandenberghe, Sucharski, \& Rhoades, 2002). Similarly, the commitment (Stinglhamber \& Vandenberghe, 2003) and trust (Aryee, Budhwar, \& Chen, 2002) literatures distinguish between the organization and supervisor foci. Taken together, these related bodies of research provide strong evidence that employees form distinct social exchange relationships with the supervisor and the organization (Karriker \& Williams, 2009; Lavelle et al., 2007; Rupp \& Cropanzano, 2002). It is highly likely that perceptions of mutual obligations (i.e., a psychological contract) underlie the employee-supervisor relationship, just as they do the employee-organization relationship (Shore et al., 2004). Supervisor obligations may include providing fair and equitable supervision, clear work direction, reward and recognition, career mentoring, and social support (Rupp \& Cropanzano, 2002; Tepper \& Taylor, 2003). If the supervisor fails to deliver on perceived obligations, it may result in subordinate perceptions of psychological contract breach with the supervisor (i.e., PCB-S).

\section{Trickle-Down Effects of Breach (Paths A and B)}

The transmission of employee perceptions, attitudes, and behaviors down the hierarchical chain from supervisors to subordinates, and even reaching customers, has been noted in a variety of research areas, including perceived organizational support (POS) and perceived supervisor support (Shanock \& Eisenberger, 2006), organizational justice (Degoey, 2000; Masterson, 2001; Tepper \& Taylor, 2003), and abusive supervision (Aryee et al., 2007; Hoobler \& Brass, 2006). In one of the early demonstrations of the trickle-down effect, Masterson (2001) proposed that the experience of organizational justice would cross over from the employee to the customer. She found that employees who experienced organizational justice were more committed to the organization, exerted extra effort, and exhibited prosocial behaviors when serving customers. Customers in turn felt that they had been fairly treated by the employees. Tepper and Taylor (2003) further extended the trickle-down approach to include the transmission of justice perceptions from supervisors to subordinates. They demonstrated that supervisors' perceptions of procedural justice were positively related to subordinate-directed citizenship behaviors (in the form of mentoring behaviors); 
these, in turn, were positively related to the subordinates' perceptions of procedural justice and OCBs.

Shanock and Eisenberger (2006) provided more direct evidence for the trickle-down effects of supervisor attitude to subordinate attitude and performance. They argued that supervisors would reciprocate high levels of support from the organization (i.e., POS) by engaging in supportive acts toward their subordinates. Such acts would enhance perceptions of supervisor support on the part of the subordinate and, in turn, lead to higher job performance by the subordinate. Shanock and Eisenberger's results showed that supervisor POS was positively related to subordinate perception of supervisor support; this latter variable mediated the relationship between supervisor POS and subordinate POS, in-role, and extrarole performance.

In addition to the positive trickle-down effects, there can also be negative repercussions for the subordinate if the supervisor has unfavorable experiences in the organization (Hoobler \& Brass, 2006). Aryee and his colleagues (2007) found that when supervisors were subjected to low interactional justice, they directed abusive supervision toward their subordinates. This trickle down of abusive behavior represents a spillover effect (where the treatment is received from one source but response is directed at another target) as opposed to the target similarity effect (where the treatment source and response target are the same; Lavelle et al., 2007). Theoretically speaking, the spillover effect can be explained by the power imbalance between the supervisor and the subordinate and the resulting displaced aggression (Marcus-Newhall, Pedersen, Carlson, \& Miller, 2000). Employees are not always able to direct their retaliation to the source of the frustration because the source may be of higher status, more powerful, or not available. In such circumstances, the subordinate may be a convenient scapegoat and becomes the target of abusive supervision (Aquino \& Lamertz, 2004; Aryee et al., 2007; Hoobler \& Brass, 2006).

Based on the literature reviewed above, we propose that supervisors' perceptions of psychological contract breach with their organizations (supervisor PCB-O) will lead to subordinate perceptions of breach with their supervisors (subordinate PCB-S). The above reasoning is supported by several lines of argument. Applying social exchange theory, we expect that the perceptions of breach will lead to supervisors reducing their contributions to the organizations (Coyle-Shapiro \& Conway, 2004; Shanock \& Eisenberger, 2006). Indeed, there is a great deal of empirical evidence for the negative consequences of breach, including a reduction in in-role performance and OCBs (Zhao et al., 2007). It is likely that some of this withdrawal in citizenship behaviors will be displaced toward the subordinates (Aquino \& Lamertz, 2004; Aryee et al., 2007) and will include reductions in mentoring (Tepper \& Taylor, 2003) and supportive activities (Shanock \& Eisenberger, 2006). Therefore, Path A in our model predicts a negative relationship between supervisor PCB-O and supervisor OCBs toward subordinates. When subordinates are the target of supervisor withdrawal, they are likely to perceive breach of psychological contract with the supervisor (or subordinate PCB-S; Path B in our model).

\section{Subordinate PCB-S, OCBs, and Customer Satisfaction (Paths C and D)}

To our knowledge, the relationship between psychological contract breach and customerfocused OCBs has not been investigated; however, theoretical reasoning and related empirical 
evidence point to this effect. Based on social exchange theory, we expect that employees will reduce discretionary contributions - such as customer-focused citizenship behaviorsin response to breach (Coyle-Shapiro \& Conway, 2004; Turnley et al., 2003). Psychological contract breach has been empirically demonstrated to be related to organization- and coworker-directed citizenship behaviors (Turnley et al., 2003; Zhao et al., 2007). There is also research evidence to show that perceptions of internal work practices, such as workplace justice (Masterson, 2001), fairness (Bettencourt \& Brown, 1997), leadership behavior, and service climate (Schneider et al., 2005), act as antecedents of customer-focused OCBs. For example, Bettencourt and Brown (1997) showed that perceptions of fairness of supervision were related to customer-focused OCBs. Therefore, we predict that if customer service employees perceive breach of their psychological contract with the supervisor, they will be less likely to engage in citizenship behaviors toward customers (Path $\mathrm{C}$ in our theoretical model).

Citizenship behaviors toward customers, such as going out of the way to ensure that customer needs are met, play an important role in enhancing the service experience of the customer (Bettencourt \& Brown, 1997; Podsakoff et al., 2000; Schneider et al., 2005). In a review of the antecedents and consequences of OCBs, Podsakoff et al. (2000) reported that OCBs can predict as much as $38 \%$ of the variance in customer satisfaction. Similarly, Masterson (2001) found that customer-focused prosocial behaviors by service providers were positively related to customer satisfaction. Therefore, the final path in our model (Path D) predicts that subordinate OCBs toward customers will be positively related to customer satisfaction.

In sum, we link supervisor perceptions of breach with subordinate perceptions of breach as well as with customer satisfaction. The pattern of relationships in our theoretical model implies a chain of mediating relationships. These mediator variables (in particular, supervisor OCBs toward subordinate and subordinate OCBs toward customers) act as explanatory variables for the trickle-down effect linking supervisor, subordinate, and customer outcomes. In the following sections, we present a programmatic series of three studies that test hypotheses derived from the theoretical model. The three studies attempt to address the what, how, and why questions that constitute a theoretical explanation (Whetten, 1989). What refers to the phenomenon under investigation, and how refers to how the constructs are related. Study 1 addresses the what and how questions: We demonstrate the trickle-down effect (what) from supervisor perception of breach to subordinate customer service and that these variables are negatively related ( how). An important question from a theoretical standpoint is why these may be related. Studies 2 and 3 then address the why question by unpacking the mediating mechanisms. Study 2 demonstrates the mediating mechanism of subordinate perceptions of breach with the supervisor (subordinate PCB-S) as the first mediating link, and Study 3 adds the final mediating link and tests the role of supervisor OCBs toward the subordinate.

\section{Study 1}

The aim of Study 1 was to test the relationship between supervisor PCB-O and customer service outcomes by the subordinate. That is, we aimed to establish the relationships between the main predictor (supervisor PCB-O) and outcome variables (subordinate OCBs toward 
customers and customer satisfaction) before further analysis of mediating trickle-down processes. Based on our theoretical model, we predict that supervisor PCB-O will be negatively related to subordinate OCBs toward customers; subordinate OCBs toward customers, in turn, will be positively related to customer satisfaction. In other words, subordinate OCBs will mediate the relationship between supervisor PCB-O and customer satisfaction.

Hypothesis 1: Subordinate OCBs toward customers will mediate the relationship between supervisor PCB-O and customer satisfaction.

\section{Method}

\section{Participants and Procedure}

The sites for this research were eight large hotels located in the central business district of Manila. The hotels were deluxe and luxury hotels, mostly serving business travelers who expected high standards of customer service. Permission to conduct a survey was obtained from the human resource manager of each hotel. The research team visited each site and held orientation sessions explaining the purpose of the survey and the procedure for survey collection. Data were obtained from three sources: (1) survey data from immediate supervisors, (2) survey data from subordinates, and (3) data from organizational records on customernominated service commendations to employees. One hundred fifty-five supervisorsubordinate dyads participated in this research (each supervisor rated only one subordinate). Among supervisors, $80 \%$ of the participants were female and $20 \%$ were male. Approximately $73 \%$ of the participants were between the ages of 31 and 45 years. Sixty-nine percent of the participants had been working in their organization between 6 and 15 years. Among subordinates, $69 \%$ of the participants were female, and $31 \%$ were male. Approximately $61 \%$ of the participants were between 26 and 35 years old. The majority of the participants $(61.9 \%)$ had been working in their organization between 1 and 5 years.

Participants were informed that we were interested in examining factors that facilitate positive employment relationships. Individual survey packets comprising subordinate and supervisor surveys and a cover letter were distributed to employees directly engaged in customer service (e.g., luggage handling, room service, housekeeping, table service in restaurants, shop assistance in hotel shops and stores, valet parking, and transportation). Information about the rationale of the study, the voluntary nature of participation, and the confidentiality of responses was provided in the cover letter. Subordinates who agreed to participate in the study completed the questionnaire on company time and passed on the supervisor forms to their immediate supervisors. Questionnaires were collected on-site by members of the research team. To allow matching of the data collected, each participant was requested to fill in a self-generated code for the self-survey and supervisor forms.

\section{Measures}

Questionnaires were prepared in English because this language is spoken by a vast majority of the Filipino population (Bernardo, 2004). The response format for all items, except the 
demographic variables, was a Likert-type scale $(1=$ strongly disagree to $7=$ strongly agree $)$, with items coded such that a higher score indicated a greater amount of the focal construct. Reliability of the measures was assessed using Cronbach's (1951) alpha coefficient.

Supervisor perceptions of psychological contract breach (supervisor PCB-O). Perceptions of psychological contract breach were assessed with five items designed to assess an overall subjective evaluation of the extent to which an individual's psychological contract had been met (Robinson \& Morrison, 2000). We chose this measure because the global assessment of breach has stronger relationships with outcome variables as compared to measures that list specific obligations or facets of psychological contracts (Zhao et al., 2007). An example item is, "So far my employer has done an excellent job of fulfilling its promises to me." Cronbach's alpha for this scale was .89.

Subordinate OCBs toward the customer. Job performance has two elements (Katz \& Kahn, 1978): in-role (formally prescribed job duties) and extra-role (discretionary activities that when performed contribute to the overall organizational goal; also referred to as OCBs). These two performance dimensions have also been identified in the context of service employees with customer contact (Schneider et al., 2005). Bettencourt and Brown (1997) noted that this distinction is salient to both employees and their managers. They developed a measure of prosocial customer service behaviors that distinguish between in-role and extra-role behaviors. We used the five-item extra-role behavior scale to measure subordinate OCBs toward the customer. This scale was particularly suited to our study because rather than list specific behaviors, which may vary for different job roles (e.g., room service vs. valet parking), it uses global assessment of the employee transcending role-prescribed behaviors when serving customers. Example items are, "I help customers/guests with problems beyond what is expected or required" and "I frequently go out of my way to help a customer/guest." This scale yielded a Cronbach's alpha of .88.

Customer satisfaction. In the hotels participating in this study, guests are routinely surveyed on their satisfaction with the service they received. This survey also allows guests to identify and name employees who have been particularly helpful and responsive to their needs. Each mention is recorded in the employee's personnel file along with unsolicited letters and notes of excellent service. This information is processed by human resources, and deserving employees are awarded a certificate of commendation for excellent customer service at the end of each month. In this study, customer satisfaction with service delivery was operationalized as the number of times an employee received a customer service commendation at Time 2 ( 3 months after the Time 1 survey of supervisors and subordinates). Sixty-seven percent of the sample received at least one commendation. To maintain confidentiality, an independent person matched the information from the employees' personnel records with the survey response, using control numbers. Neither the organizational representatives nor the research team had access to both pieces of information.

Demographic variables. We measured supervisor and subordinate gender, age, and organizational tenure. Gender was coded as 0 for male and 1 for female. Age was measured in 
Table 1

Descriptive Statistics and Zero-Order Correlations of Study 1 Variables

\begin{tabular}{|c|c|c|c|c|c|c|c|c|c|c|}
\hline Variable & $M$ & $S D$ & 1 & 2 & 3 & 4 & 5 & 6 & 7 & 8 \\
\hline 1. Subordinate gender & 0.69 & 0.46 & & & & & & & & \\
\hline 2. Subordinate age & 3.66 & 1.51 & $-.30 *$ & & & & & & & \\
\hline 3. Subordinate tenure & 2.58 & 1.56 & -.15 & $.84 * * *$ & & & & & & \\
\hline 4. Supervisor gender & 0.80 & 0.40 & $.33 * * *$ & $-.19 *$ & $-.25^{* *}$ & & & & & \\
\hline 5. Supervisor age & 5.45 & 1.30 & -.05 & $.20^{*}$ & $.21 * *$ & .06 & & & & \\
\hline 6. Supervisor tenure & 3.75 & 1.36 & .10 & $.28 * * *$ & $.32 * * *$ & .10 & $.51^{* * *}$ & & & \\
\hline 7. Supervisor PCB-O & 2.19 & 1.12 & -.04 & .14 & $.21 * *$ & $-.35 * * *$ & $-.52 * * *$ & $-.35^{* * *}$ & $(.87)$ & \\
\hline $\begin{array}{l}\text { 8. Subordinate customer- } \\
\text { focused OCBs }\end{array}$ & 5.94 & 0.92 & -.01 & -.11 & -.21 & $.29 * * *$ & $.18^{*}$ & .05 & $-.32 * * *$ & (.89) \\
\hline 9. Customer satisfaction & 1.35 & 0.71 & .04 & .05 & .02 & .09 & .10 & .01 & $-.19 *$ & $.27 * * *$ \\
\hline
\end{tabular}

Note: Alpha coefficients, in parentheses, are along the diagonal. PCB-O = perceptions of psychological contract breach-organization; OCBs = organizational citizenship behaviors. Gender is coded as $0=$ male and $1=$ female; age is coded as $1=20$ years and under, $2=21-25$ years, $3=26-30$ years, $4=31-35$ years, $5=36-40$ years, $6=$ 41-45 years, $7=46-50$ years, and $8=$ over 50 years; tenure is coded as $1=$ less than a year, $2=1-5$ years, $3=6-10$ years, $4=11-15$ years, $5=16-20$ years, $6=21-25$ years, $7=26-30$ years, and $8=$ over 30 years. $N=155$. $* p<.05 . * * p<.01 . * * * p<.001$

5 -year age bands $(1=20$ years and under, $2=21$ to 25 , and so on until $8=$ over 50 years $)$. Tenure was also measured in 5 -year age bands $(1=$ less than 1 year, $2=1$ to 5 years, and so on until $8=$ over 30 years).

\section{Results}

Descriptive statistics, zero-order correlations, and reliability coefficients are presented in Table 1. All measures had acceptable levels of reliability (Nunnally, 1978). To determine whether there were significant variations in the study variables across the eight hotels, we compared these hotels on all study variables. There were no significant differences across the hotels in terms of supervisor's experiences of psychological contract breach, $F(7,147)=$ $0.65, n s$; subordinate OCBs toward the customer, $F(7,147)=0.40, n s$; and archival records of customer service commendations, $F(7,147)=0.71$, $n s$.

To test the hypothesis, we used structural equation modeling (SEM) as our analytic technique. When testing for mediation, an SEM-based approach has several advantages over the regression-based approach, including the simultaneous assessment of the relationships between the antecedent, mediating, and outcome variables; the modeling of manifest and latent variables; and an assessment of the fit of the model against the data (see LeBreton, $\mathrm{Wu}, \&$ Bing, 2009, for a detailed discussion of the SEM approach in testing mediating relationships). We conducted a two-step procedure in order to estimate the relationships among the study variables (Anderson \& Gerbing, 1988). In the first step, we estimated the measurement model to establish the discriminant validity of the variables under investigation. In the second step, we examined structural models to test the study hypothesis.

In addition to the $\chi^{2}$ as an indicator of fit, we report $\chi^{2} / d f$, the comparative fit index (CFI), and the root mean square error of approximation (RMSEA) for each of our models. Bludau, 
Herman, Williams, and Cortina (2007) recommend the use of CFI and RMSEA, as these two indices provide complementary information and together capture Tanaka's (1993) six dimensions that classify fit indices (i.e., population based vs. sample based, simple vs. complex, normed vs. nonnormed, absolute vs. relative, estimation method vs. estimate method specific, and sample size independent vs. sample size dependent). A $\chi^{2} / d f$ value of less than 3 indicates good fit (Kline, 1998). Values for the CFI can range from 0 to 1.00, with values close to 1.00 indicative of good fit. Scores of more than .95 suggest a good-fitting model (Hu $\&$ Bentler, 1999). An RMSEA value of .08 or less is indicative of adequate fit (Kline, 1998).

Measurement model. We created item parcels in order to improve the ratio of $N$ relative to the number of parameters to be estimated (Little, Cunningham, Shahar, \& Widaman, 2002). An item parcel represents an aggregate-level indicator comprising the average of two or more items (Little et al., 2002). Parceling is justified when the primary purpose of the analysis is to model structural relationships between the latent variables (Williams, Vandenberg, $\&$ Edwards, 2009). There are various approaches for selecting items to combine (Hodgkinson $\&$ Sadler-Smith, 2003). We used the factorial algorithm approach, which is the recommended approach when the measure is unidimensional (Williams et al., 2009). In this approach, factor analysis is used to guide the allocation of items to parcels. Specifically, the items with the highest and lowest loadings for each construct are collapsed first, followed by the items with the next second highest and lowest loadings, thereby ensuring that parcels are "equally balanced in terms of their difficulty and discrimination" (Williams et al., 2009: 550). Supervisor perceptions of breach associated with the organization and subordinate customerfocused OCBs were each assessed with three parcels. The resulting measurement model had a good fit with the observed data, $\chi^{2}(8, N=155)=2.08, n s, \chi^{2} / d f=0.26, \mathrm{CFI}=.99$, RMSEA $=$ .00 (confidence interval [CI] 90\%:.00-.00). The standardized path estimates of the manifest indicators (ranging between .76 and .99) were all statistically significant. We also compared this measurement model with a one-factor model. Results of the chi-square difference test between the measurement model (two-factor model) and the one-factor model suggested that the former had the better fit, $\chi^{2}(9, N=155)=122.62, p<.001, \chi^{2} / d f=13.62$, CFI $=.81$, RMSEA $=.29$ (CI 90\%: .24-.33), $\chi_{\text {diff }}^{2}(1)=120.54, p<.001$.

Structural model. We tested the hypothesized fully mediated structural model by specifying paths from supervisor PCB-O to subordinate OCBs toward customers and from subordinate OCBs toward customers to customer satisfaction. Given that customer satisfaction was measured using a single indicator, we set the path from the indicator variable to the latent variable equal to the square root of the reliability of the observed score (estimated to be .90; Mathieu, Tannenbaum, \& Salas, 1992). Also, the random error variance was set as 1 minus the reliability of the observed score times the variance of the observed score. The hypothesized structural model (Model A; see Figure 2) had a good fit, $\chi^{2}(13, N=155)=8.29, n s, \chi^{2}$ / $d f=0.64, \mathrm{CFI}=1.00, \mathrm{RMSEA}=.00(\mathrm{CI} 90 \%: .00-.05)$. All the predicted paths were significant at $p<.001$. To examine the partially mediated structural model, we added one additional path representing direct effect from supervisor perceptions of breach with the organization and customer satisfaction. The direct path was nonsignificant (path coefficient $=$ -.10 ). The fit indices of the partially mediated model (Model B) are $\chi^{2}(12, N=155)=6.71$, 


\section{Figure 2}

Final Structural Model for Study 1

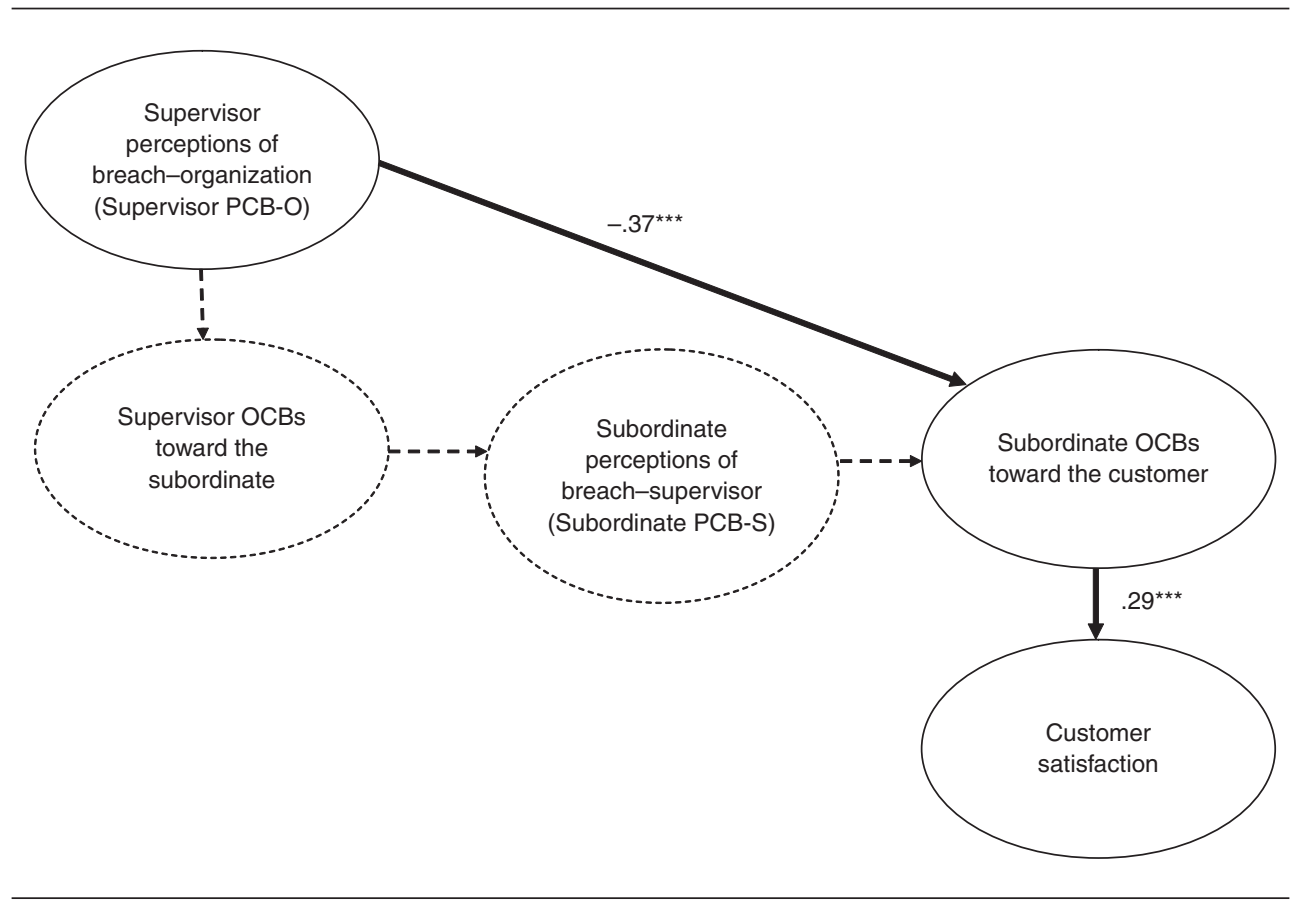

Note: Bold lines represent paths tested in this study. All path coefficients are significant at $p<.001$.

$p<.001, \chi^{2} / d f=0.56, \mathrm{CFI}=1.00, \mathrm{RMSEA}=.00$ (CI 90\%: .00-.041). Results of the chisquare difference test suggested that the partially mediated model did not have a better fit compared to Model A, $\chi_{\text {diff }}^{2}(1)=1.58, n s$. Thus, Model A was accepted as the final model, supporting Hypothesis 1 .

The indirect effect from supervisor PCB-O to customer satisfaction via subordinate OCBs toward customers was -.09 . We conducted the Sobel test (Sobel, 1982) to formally assess the significance of the indirect effect. Results revealed that the indirect path was significant at $p<.05$. In addition, we assessed the indirect effect using the product of coefficient method and generated asymmetric confidence intervals using PRODCLIN2 (MacKinnon, Fritz, Williams, \& Lockwood, 2007). The 95\% confidence intervals for this indirect effect ranged from -.15 to -.03 . These values did not include a zero and indicate support for Hypothesis 1 .

\section{Discussion}

The findings of this study provide evidence for the trickle-down effect of supervisor PCB-O upon customer service outcomes by the subordinate. As predicted by Hypothesis 1, 
subordinate OCBs toward the customer mediated the effect of supervisor PCB-O upon quality of customer service. Supervisor PCB-O was negatively related to subordinate OCBs toward the customer, which in turn was positively related to quality of customer service by the subordinate as reflected in the number of commendations awarded to the subordinate. These results demonstrate the impact of supervisor PCB-O upon customer service via actions of the subordinate. Having demonstrated the relationship between supervisor psychological contract breach and customer service outcomes by the subordinate, in the following studies we analyze the mediating mechanisms between these variables.

\section{Study 2}

The aim of Study 2 was to examine the mediating effect of subordinate perceptions of breach with supervisor (subordinate PCB-S) in the relationship between supervisor PCB-O and subordinate OCBs toward the customer. Whereas in Study 1 we used organizational commendations as the measure of quality of customer service, in Study 2 we obtained more direct evidence of the quality of customer service by measuring customer ratings of satisfaction with the service provided by the subordinate. Based on our theoretical model, we make the following predictions:

Hypothesis 2a: Subordinate PCB-S will mediate the relationship between supervisor PCB-O and subordinate OCBs toward the customer.

Hypothesis 2b: Subordinate OCBs toward the customer will mediate the relationship between subordinate PCB-S and customer satisfaction.

\section{Method}

\section{Participants and Procedure}

Data were collected from various restaurant and food outlets located in metropolitan Manila. Permission was sought from restaurant owners attending a professional development course on restaurant management at a large private university. Research assistants held orientation sessions at each restaurant and explained the purpose of the research and the survey procedure. Survey packs were distributed to a total of 300 fast-food and restaurant workers, of which we received 140 completed self- and supervisor questionnaires. The survey pack included an information sheet (stating the aims of the study and assuring confidentiality of response and voluntary nature of participation), self-report questionnaire, and supervisor questionnaire. Each supervisor only rated one subordinate. One month after this survey, we collected customer ratings of satisfaction. With the consent of senior management and the employee, research assistants administered a brief customer service form to a customer who had been served by the employee. Subordinates were aware that customer satisfaction ratings were being collected by research assistants, and this may have affected the service provided to customers. To minimize the effects of possible differential treatment, research assistants randomly selected a single customer who had been served by each 
participating employee. To allow matching of the data collected, each participant was requested to fill in a self-generated code on the self-survey, supervisory form, and customer service form.

Among subordinate participants, 54.3\% were female. More than half of the participants $(62.9 \%)$ were between 21 and 25 years old. The majority $(86.4 \%)$ had been working for their organization between 1 and 5 years. As for the supervisor participants, $43.6 \%$ were female. More than half of the supervisors (58.5\%) were between the age groups of 26 and 35. Fifty-two percent of the supervisors had been working for their organization between 6 and 15 years.

\section{Measures}

Similar to Study 1, questionnaires were prepared in English and used a 7-point Likerttype scale.

Supervisor perceptions of psychological contract breach-organization (supervisor PCB-O). Supervisor perceptions of psychological contract breach were assessed in the same manner as in Study 1. In this study, the scale yielded a coefficient alpha of .87.

Subordinate perceptions of psychological contract breach-supervisor (subordinate PCB-S). We used the five-item scale developed by Robinson and Morrison (2000) and modified it by replacing the term "organization" with "supervisor." This scale yielded a Cronbach's alpha of $.89 .^{1}$

Subordinate OCBs toward the customer. Supervisors were asked to rate their subordinates' OCBs toward the customer, using the same scale as in Study 1. In this study, the scale yielded a Cronbach's alpha of .93 .

Customer ratings of satisfaction. We assessed customer satisfaction using the scale developed by Tsiros, Mittal, and Ross (2004). Customers were requested to provide ratings of satisfaction with respect to the service they had received from the employees. An example item is, "I am pleased with the service extended to me by this employee," This three-item scale yielded a Cronbach's alpha of .95 .

Demographic variables. Similar to Study 1, we measured the supervisor and subordinate demographic characteristics of age, gender, and organizational tenure.

\section{Results}

Data were analyzed using the same methods described in Study 1. The means, standard deviations, zero-order correlations, and coefficient alphas for the study variables are displayed in Table 2. Zero-order correlations were all in the expected direction. All measures had acceptable levels of reliability. Because data were collected from different restaurants and fast-food outlets, we tested for organization-level effects. However, univariate analysis showed that, across the various sample sites, there were no significant differences in 


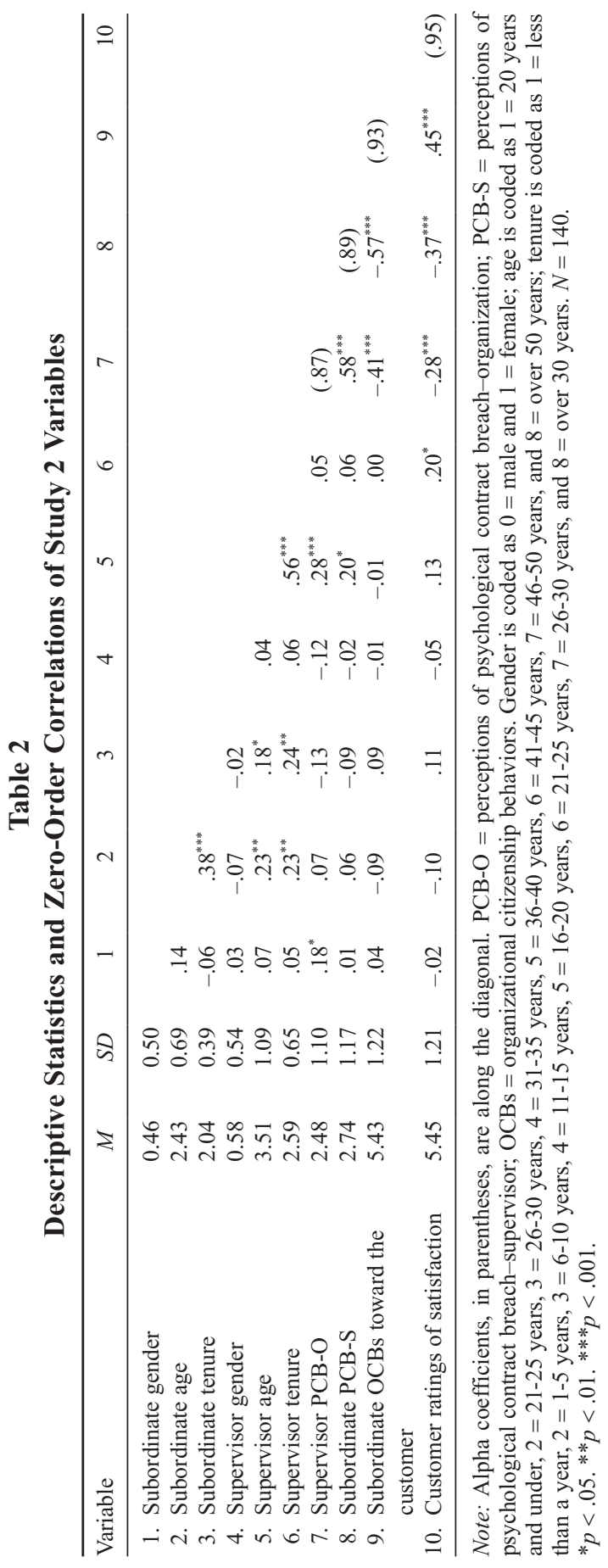


supervisor perceptions of breach associated with the organization, $F(32,107)=1.21$, $n s$; subordinate perceptions of breach associated with the supervisor, $F(32,107)=0.96, n s$; supervisor ratings of subordinate OCBs toward the customer, $F(32,107)=1.22$, $n s$; and customerrated satisfaction, $F(32,107)=1.19$, $n s$.

Measurement model. As in Study 1, we created item parcels in order to improve the ratio of $N$ relative to the number of parameters to be estimated (Little et al., 2002). Based on factor analytic results, the items with the highest and lowest loadings for each construct were collapsed first, followed by the items with the next second highest and lowest loadings. The hypothesized measurement model had a good fit with the observed data, $\chi^{2}(48, N=140)=$ $83.3, p<.001, \chi^{2} / d f=1.74, \mathrm{CFI}=.97, \mathrm{RMSEA}=.073$ (CI 90\%: .046-.09). The standardized path estimates of the manifest indicators (ranging between .72 and .99) were all statistically significant.

We also compared this measurement model with several alternative models. Model 1 incorporated all four constructs into one factor, $\chi^{2}(54, N=140)=343.37, p<.001, \chi^{2} / d f=$ $6.36, \mathrm{CFI}=.79$, RMSEA $=.20$ (CI 90\%: .18-.20). Model 2 combined measures based on source; thus, supervisor measures were combined (supervisor PCB-O and supervisor ratings of subordinate OCBs toward the customer) into Factor 1, subordinate PCB-S into Factor 2, and customer ratings of satisfaction into Factor $3, \chi^{2}(49, N=140)=175.65, p<.001, \chi^{2} / d f=$ $3.59, \mathrm{CFI}=.91$, RMSEA $=.14$ (CI 90\%: .12-.16); Model 1 versus Model 2, $\chi_{\text {diff }}^{2}(5)=$ 167.72., $p<.01$. Model 3 combined the two psychological contract constructs (supervisor PCB-O and subordinate PCB-S) into Factor 1 and the two customer-related constructs (subordinate OCBs toward the customer and customer ratings of satisfaction) into Factor 2, $\chi^{2}(50, N=140)=90.13, p<.001, \chi^{2} / d f=1.80, \mathrm{CFI}=.97, \mathrm{RMSEA}=.076(\mathrm{CI} 90 \%: .05-.10)$; Model 2 versus Model 3, $\chi_{\text {diff }}^{2}(1)=85.52, p<.001$. Results of the chi-square difference test between our measurement model (four-factor model) and the best fitting three-factor model (Model 3) suggested that the former had the best fit; final measurement model versus Model 3, $\chi_{\text {diff }}^{2}(2)=6.83, p<.05$.

Structural model. To test our hypothesized structural model, we specified paths from supervisor PCB-O to subordinate PCB-S, from subordinate PCB-S to subordinate OCBs toward the customer, and from subordinate OCBs toward the customer to customer ratings of satisfaction. The hypothesized structural model (Model A; see Figure 3) had a good fit, $\chi^{2}(51, N=140)=88.99, p<.001, \chi^{2} / d f=1.75$, CFI $=.97$, RMSEA $=.073($ CI 90\%: .047.097). All the predicted paths were significant at $p<.001$. To compare this model to a partially mediated structural model, we added three additional paths representing direct effects: (1) a path linking supervisor PCB-O and subordinate OCBs toward the customer, (2) a path linking supervisor PCB-O and customer satisfaction, and (c) a path linking subordinate PCB-S and customer satisfaction. These additional paths were not statistically significant. The fit indices of the partially mediated model (Model B) are $\chi^{2}(48, N=140)=$ 83.33, $p<.001, \chi^{2} / d f=1.74, \mathrm{CFI}=.97$, RMSEA $=.073$ (CI 90\%: .047-.098). Results of the chi-square difference test suggested that the partially mediated model did not have a better fit compared to the hypothesized Model A; $\chi_{\text {diff }}^{2}(3)=5.66, n s$. We accepted Model A as the final model. 


\section{Figure 3}

\section{Final Structural Model for Study 2}

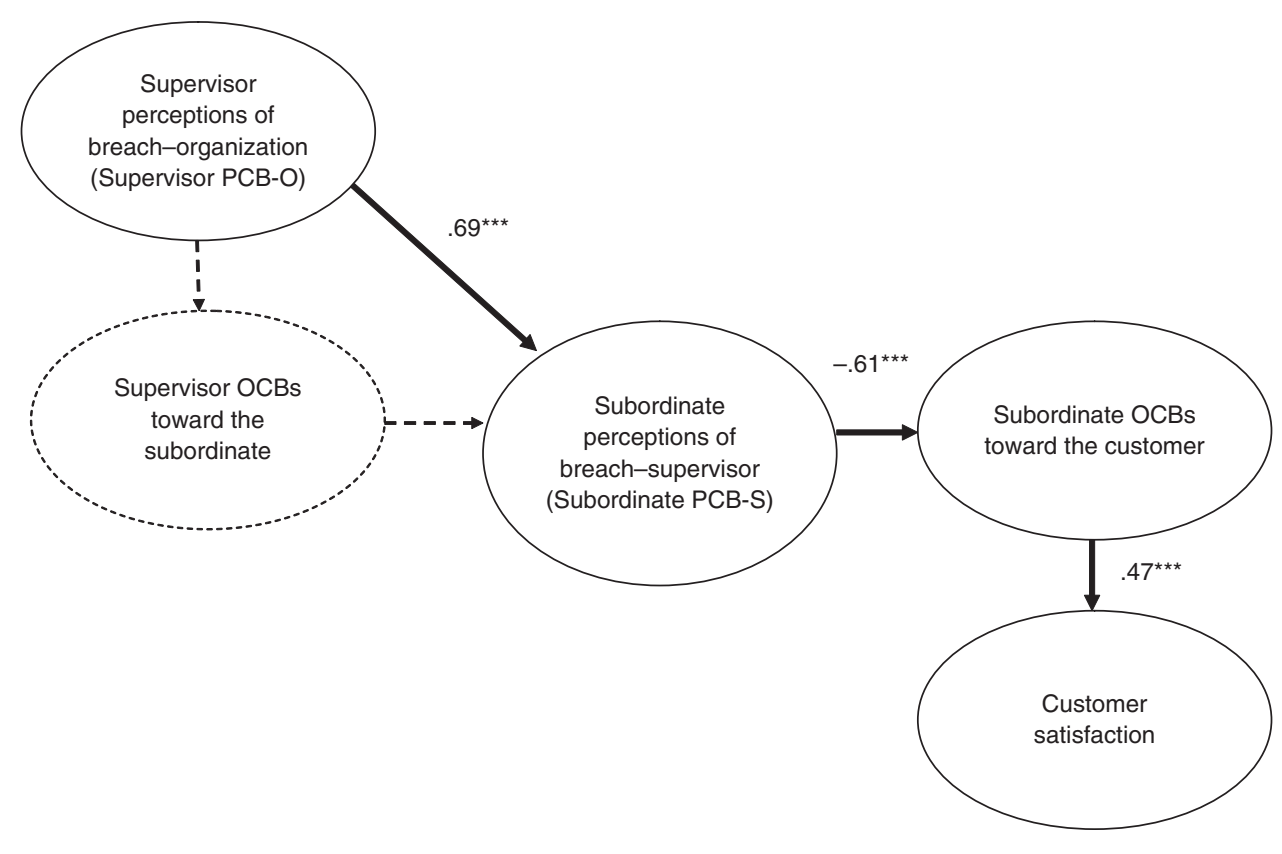

Note: Bold lines represent paths tested in this study. All path coefficients are significant at $p<.001$.

We next assessed the two indirect effects. The indirect effect from supervisor PCB-O to subordinate OCBs toward customers via subordinate PCB-S was -0.59 . Results from the Sobel test $(p<.001)$ and the asymmetric $95 \%$ confidence intervals $(-.80$ to -.40 ; MacKinnon et al., 2007) supported Hypothesis 2a. The indirect effect from subordinate PCB-S to customer satisfaction via subordinate $\mathrm{OCBs}$ toward customers was -0.30 . Once again, results from the Sobel test $(p<.001)$ and asymmetric confidence intervals $(-.44$ to -.18$)$ supported Hypothesis $2 b$.

\section{Discussion}

To our knowledge, this is the first study to link psychological contract breach perceptions of supervisors and subordinates. The findings of this study supported the theoretical propositions derived from our model of trickle-down effects of psychological contract breach. Hypothesis 2a predicted that supervisor PCB-O will be related to subordinate PCB-S, which in turn will be related to subordinate OCBs toward customers. Supervisor PCB-O was positively related to subordinate PCB-S. Further, subordinate PCB-S was negatively related to 
customer satisfaction and-supporting Hypothesis $2 \mathrm{~b}$ - subordinate OCBs toward the customer mediated this relationship. Thus, using a different operationalization from Study 1, we were again able to demonstrate the negative consequences of the trickle-down effects of psychological contract breach on customer service.

In developing the rationale for why supervisor PCB-O should lead to subordinate PCB-S, we applied the findings of Tepper and Taylor (2003) that supervisors reduce subordinate mentoring and OCBs when they experience injustice; we expected this withdrawal of OCBs to lead to subordinate perceptions of breach with the supervisor. However, we did not explicitly test the mediating role of supervisor OCBs toward the subordinate. Also, we did not explore whether the supervisor's actions led the subordinate to perceive a more generalized perception of breach with the organization (i.e., subordinate PCB-O). The next study addresses these issues.

\section{Study 3}

In this study, we had two broad aims. First, we wanted to examine the mechanism by which supervisor PCB-O trickles down to subordinate PCB-S. Our theoretical model predicts that supervisor PCB-O will be negatively related to supervisor OCBs toward the subordinate (Path A), and that, in turn, will be negatively related to subordinate PCB-S (Path B). In other words, we expect supervisor OCBs to mediate the relationship between supervisor PCB-O and subordinate PCB-S. Also based on our theoretical model, we predict that subordinate PCB-S will mediate between supervisor OCBs toward subordinate and subordinate OCBs toward the customer. Therefore, we propose the following hypotheses.

Hypothesis 3a: Supervisor OCBs toward the subordinate will mediate the relationship between supervisor PCB-O and subordinate PCB-S.

Hypothesis 3b: Subordinate PCB-S will mediate the relationship between supervisor OCBs toward the subordinate and subordinate OCBs toward the customer.

Second, we wanted to consider the implications of supervisor PCB-O for subordinate perceptions of breach with the supervisor as well as the organization foci. An essential element of our trickle-down explanation has been the multifoci approach to breach: Given that we investigated subordinate breach perceptions as a consequence of supervisor actions (withdrawal of OCBs), we would expect this effect to be most visible with the supervisor foci (i.e., PCB-S). However, there might also be generalized consequences for subordinate perception of psychological contract breach by the organization (or subordinate PCB-O). Shanock and Eisenberger (2006) found that supervisor POS was related to subordinate perception of POS as well as to perception of supervisor support. The supervisor is an important agent of the organization (Shore \& Tetrick, 1994; Tekleab \& Taylor, 2003); therefore, we expect that lack of OCBs from the supervisor will also lead to perceptions of psychological contract breach with the organization (subordinate PCB-O). However, given the one-to-one correspondence among the foci, we expect supervisor OCBs toward the subordinate to have a stronger relationship with subordinate PCB-S than with subordinate PCB-O (Lavelle et al., 2007). 
Hypothesis 3c: Supervisor OCBs toward the subordinate will mediate the relationship between supervisor PCB-O and subordinate PCB-O.

Hypothesis 3d: The relationship of supervisor OCBs toward the subordinate with subordinate PCB-S will be stronger than the relationship with subordinate PCB-O.

\section{Method}

\section{Participants and Procedure}

Data were collected from 17 call center sites throughout the capital city of Manila and nearby provinces within Luzon in the Philippines. These were all independent call centers; however, all were closely regulated by the industry body (Call Centre Association of the Philippines) and had similar human resource policies. Human resource managers were contacted, and permission was sought to distribute surveys. As in Studies 1 and 2, research assistants held orientation sessions at each location, providing a brief explanation of the study and the survey procedure. Participants were provided a survey kit with an accompanying cover letter stating the goals of the project and assuring confidentiality. Three hundred customer service workers received a self-report survey assessing supervisor OCBs toward subordinates, subordinate PCB-O, and subordinate PCB-S. In addition, the immediate supervising officer of each of these employees received a survey measuring supervisor $\mathrm{PCB}-\mathrm{O}$ and requested him or her to assess the customer-oriented behaviors of the respective subordinates. The supervising officers were identified by the human resources department as someone who interacted with the focal employee and in a position to supervise and provide performance-related feedback.

One hundred seventy-two employees and their respective supervising officers responded to the surveys. Each supervising officer rated only one subordinate. To allow matching of the data collected, each participant was requested to fill a self-generated code on the selfsurvey, supervisory form, and customer service form. Among the customer service workers, 57.6\% were female. A large majority $(90.7 \%)$ were between 21 and 30 years old. Sixty percent had been working for their respective organizations between 1 and 5 years. As for the supervising officers, 57.6\% were female. Eighty-three percent were between 26 and 35 years old. Sixty-eight percent had been working for their respective companies between 1 and 5 years. Supervising officers knew their respective subordinates for an average of 15 months.

\section{Measures}

Similar to Studies 1 and 2, questionnaires were prepared in English and used a 7-point Likert-type scale for all measures.

Supervisor perceptions of psychological contract breach (supervisor PCB-O). As in Study 1, supervisor perceptions of breach with the organization $(\alpha=.91)$ was assessed with the measure taken from Robinson and Morrison (2000). 
Supervisor OCBs toward the subordinate (subordinate ratings). Similar to the approach used by Tepper and Taylor (2003), our measure of supervisor OCBs toward the subordinate was derived from Ragins and McFarlin (1990) and included four items that tapped into two dimensions of supervisory mentoring: protection ("My supervisor shields me from damaging contact with important people in the organization" and "My supervisor protects me from those who are out to get me") and support ("My supervisor is someone I can confide in" and "My supervisor provides support and encouragement"). Subordinates were asked to rate their supervisors on these dimensions. This scale yielded a reliability coefficient of .94 .

Subordinate perceptions of psychological contract breach. Subordinate perceptions of psychological contract breach were assessed with two referents: subordinate PCB-S and subordinate PCB-O. We used the five-item scale developed by Robinson and Morrison (2000) and modified the scale by using the terms "supervisor" and "organization" to assess subordinate PCB-S and subordinate PCB-O, respectively. The reliability of the PCB-S and PCB-O scales were .83 and .85 , respectively.

Subordinate OCBs toward the customer (supervisor ratings). As in Study 1, subordinate OCBs toward the customer were measured with five items developed by Bettencourt and Brown (1997). This scale yielded a Cronbach's alpha of .95 .

Demographic variables. As in Studies 1 and 2, we measured the age, gender, and organizational tenure of the supervisors and subordinates.

\section{Results}

Data were analyzed using the same methods described in Studies 1 and 2. Descriptive statistics, intercorrelations, and coefficient alphas for the study variables are depicted in Table 3. All coefficient alphas were acceptable, and the zero-order correlations were all in the expected direction. Because our data were collected from 17 call center organizations, we compared the organizations on all the study variables. There were no significant differences between the samples on any of the study variables: supervisor PCB-O, $F(16,155)=$ $1.09, n s$; supervisor OCBs toward the subordinate, $F(16,155)=0.40, n s$; subordinate PCB$\mathrm{O}, F(16,155)=0.75$, ns; subordinate $\mathrm{PCB}-\mathrm{S}, F(16,155)=0.17$, ns; and supervisor ratings of subordinate OCBs toward the customer, $F(16,155)=0.65$, ns.

Measurement model. Similar to Studies 1 and 2, we created item parcels in order to improve the ratio of $N$ relative to the number of parameters to be estimated (Little et al., 2002). Based on factor analytic results, the items with the highest and lowest loadings for each construct were collapsed first, followed by the items with the second highest and lowest loadings. The measurement model had an acceptable fit with the observed data, $\chi^{2}(67$, $N=172)=156.92, p<.001, \chi^{2} / d f=2.34$, CFI $=.96$, RMSEA $=.089($ CI 90\%: .071-.10). The standardized path estimates of the manifest indicators (ranging from .49 to .99) were all statistically significant. 


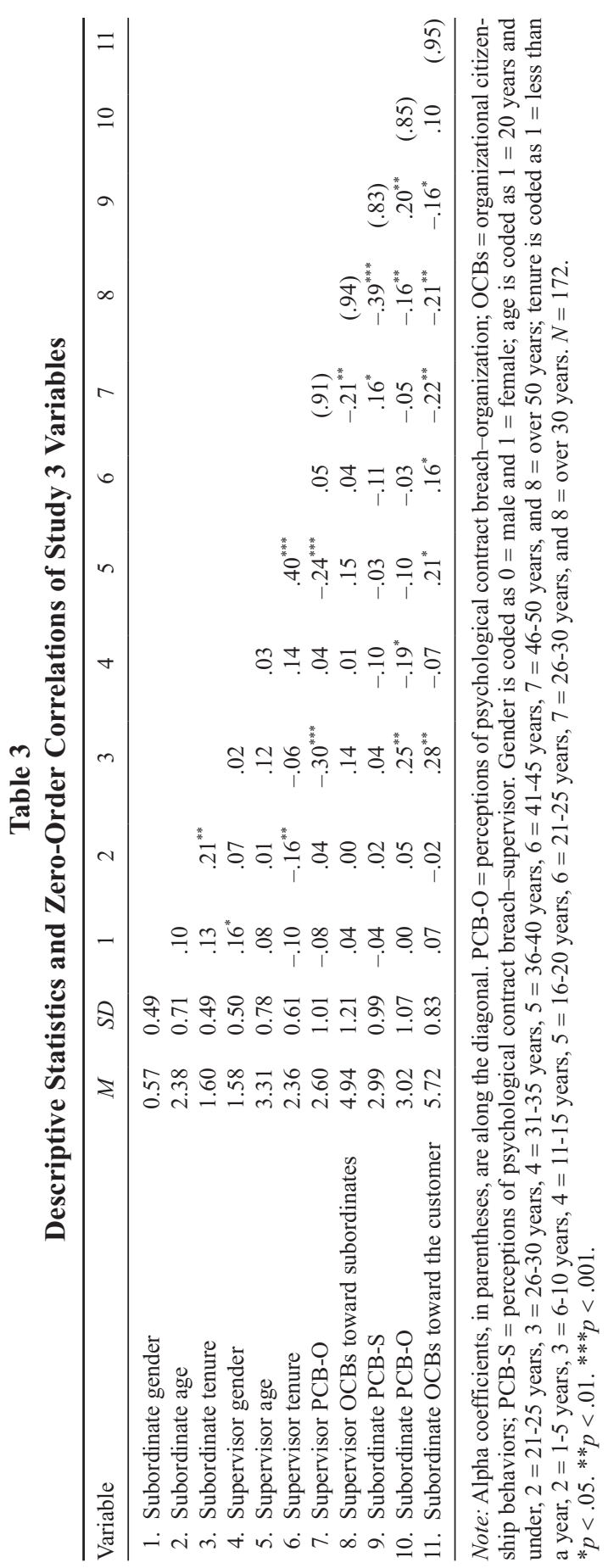


We also compared the measurement model with several alternative models. In Model 1, all items were loaded onto one factor, $\chi^{2}(76, N=172)=759.99, p<.001, \chi^{2} / d f=10.00, \mathrm{CFI}=$ .70 , RMSEA = .23 (CI 90\%: .22-.24). In Model 2a, the supervisor-rated measures (supervisor PCB-O and subordinate OCBs toward the customer) were loaded onto Factor 1 and subordinate-rated measures (supervisor OCBs toward the subordinate, subordinate PCB-O, and subordinate PCB-S) were loaded onto Factor $2, \chi^{2}(71, N=172)=393.32, p<.001, \chi^{2}$ $d f=5.54, \mathrm{CFI}=.86, \mathrm{RMSEA}=.16\left(\mathrm{CI} 90 \%\right.$ : .15-.18); Model 1 versus Model $2 \mathrm{a}, \chi_{\text {diff }}^{2}(5)=$ $366.67, p<.001$. In Model 2b, the psychological contract constructs were combined (supervisor PCB-O, subordinate PCB-O, and subordinate PCB-S) into Factor 1, and customeroriented and OCB behaviors were combined into Factor $2, \chi^{2}(71, N=172)=249.74, p<$ $.001, \chi^{2} / d f=3.52, \mathrm{CFI}=.92, \mathrm{RMSEA}=.12(\mathrm{CI} 90 \%: .11-.14)$; Model 1 versus Model 2b, $\chi_{\text {diff }}^{2}(5)=510.25, p<.001$. In Model 3, the psychological contract constructs were combined (supervisor PCB-O, subordinate PCB-O, and subordinate PCB-S) and loaded onto Factor 1; customer-oriented measure (subordinate OCBs toward the customer) loaded onto Factor 2; and supervisor OCBs toward the subordinate loaded onto Factor $3, \chi^{2}(70, N=172)=233.04$, $p<.001, \chi^{2} / d f=3.34, \mathrm{CFI}=.93, \mathrm{RMSEA}=.12$ (CI 90\%: .10-.13); Model 2b versus Model 3, $\chi_{\text {diff }}^{2}(1)=16.7, p<.001$. Results of the chi-square difference test between our measurement model (five-factor model) and Model 3 suggested that the former had the best fit; final measurement model versus Model 3, $\chi_{\text {diff }}^{2}(3)=76.12, p<.01$.

Structural model. To begin with, we tested the hypotheses in the form of the model depicted in Figure 4. This fully mediated model (Model A) had a good fit, $\chi^{2}(73, N=172)=$ $170.54, p<.001, \chi^{2} / d f=2.30, \mathrm{CFI}=.96, \mathrm{RMSEA}=.085$ (CI 90\%: .070-.10). The path from subordinate PCB-O to subordinate OCBs toward the customers was not significant and therefore dropped. All other predicted path coefficients were significant at $p<.01$.

To examine the partially mediated structural model (Model B), we specified three additional paths representing direct effects: (1) a path linking supervisor PCB-O and subordinate PCB-S, (2) a path linking supervisor PCB-O and subordinate PCB-O, and (3) a path linking supervisor OCBs toward the subordinate and subordinate OCBs toward the customer. Results showed that these additional paths were nonsignificant. The fit indices of the partially mediated model $\left(\right.$ Model B) are $\chi^{2}(70, N=172)=163.87, p<.001, \chi^{2} / d f=2.34, \mathrm{CFI}=.96, \mathrm{RMSEA}=.089(\mathrm{CI}$ $90 \%$ : .071-.11). Results of the chi-square difference test suggested that the partially mediated model did not have a better fit compared to Model A; $\chi_{\text {diff }}^{2}(3)=6.67, n s$. We accepted Model $\mathrm{A}$ as the final model (see Figure 4 for the standardized path estimates).

The indirect effect from supervisor PCB-O to subordinate PCB-S via supervisor OCBs toward the subordinate was 0.10 . The Sobel test revealed that this indirect effect was significant $(p<.05)$ and the $95 \%$ asymmetric confidence intervals ranged from .03 to .17, supporting Hypothesis 3a. The indirect effect from supervisor OCBs toward the subordinate to subordinate OCBs toward customers via subordinate PCB-S was 0.06. This indirect effect was also significant at $p<.05$, and the $95 \%$ asymmetric confidence intervals ranged from .01 to .11. Thus, Hypothesis $3 \mathrm{~b}$ was supported. Finally, the indirect effect from supervisor PCB-O to subordinate PCB-O via supervisor OCBs toward the subordinate was 0.07 . This indirect effect was also statistically significant $(p<.05)$, and the $95 \%$ asymmetric confidence intervals ranged from .01 to .13 . Hypothesis $3 \mathrm{c}$ was supported. 
Figure 4

Final Structural Model for Study 3

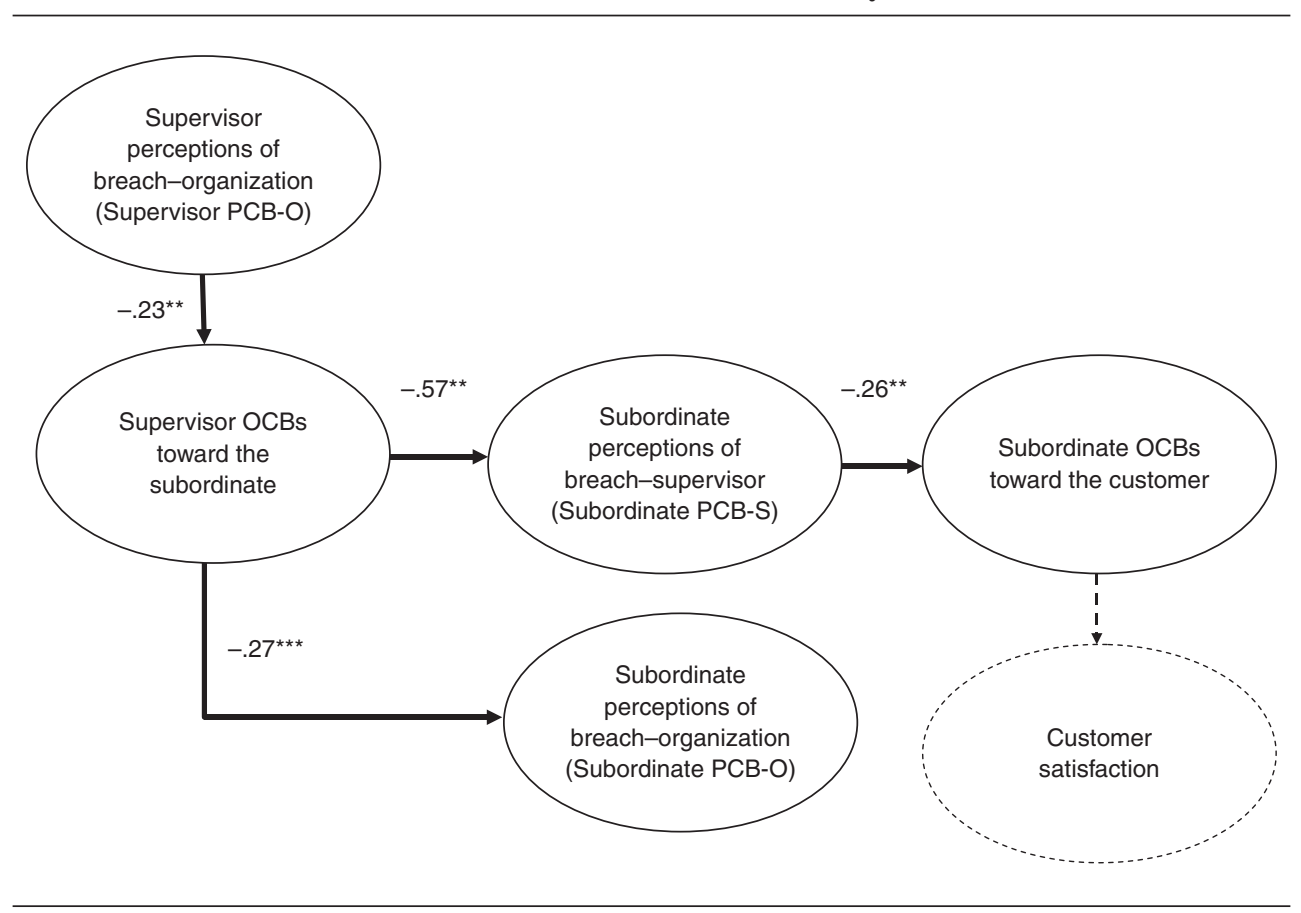

Note: Bold lines represent paths tested in this study. All paths coefficients are significant at $p<.01$.

Hypothesis $3 \mathrm{~d}$ predicted that the relationship between supervisor OCBs toward the subordinate and subordinate PCB-S will be stronger than the relationship between supervisor OCBs toward the subordinate and subordinate PCB-O; these two correlations were -.39 and -.16 , respectively. Steiger's test (which analyzes the difference in the strength of dependent correlations; Steiger, 1980) revealed a significant difference between these relationships $t(169)=6.01(p<.001)$. Hypothesis $3 \mathrm{~d}$ was thus supported.

\section{Discussion}

In this study, we wanted to examine the mechanism linking supervisor and subordinate perceptions of breach. As predicted by Hypothesis 3a, we found that supervisor OCBs toward the subordinate mediated the relationship between supervisor PCB-O and subordinate PCB-S. Supervisor OCBs toward the subordinate was also related to subordinate PCB-O (Hypothesis 3c), emphasizing the importance of the supervisor as a key agent of the organization. However, this relationship was weaker than the relationship between supervisor OCBs toward the subordinate and subordinate PCB-S. Hypothesis $3 \mathrm{~d}$ was thus supported; 
this finding is not surprising given that both these variables are associated with the supervisor referent. Actions by other agents of the organization (senior managers and human resource managers) are also likely to contribute to subordinate perceptions of PCB-O (Dulac et al., 2008). As predicted in our model, it was subordinate PCB-S that was related to subordinate OCBs toward the customer and not subordinate PCB-O. This strengthens the proposed explanation of subordinate PCB-S as the trickle-down mechanism.

\section{General Discussion}

The aim of this article was to investigate the trickle-down effects of supervisor and subordinate perceptions of breach upon customer service. We addressed several gaps in the literature. In a review and assessment of the research applications of social exchange theory, Coyle-Shapiro and Conway (2004) noted that there is a lack of research on how various social exchange-based relationships - such as between the organization and the employee, between supervisors and subordinates, and between coworkers-influence each other. A given exchange relationship occurs in the context of the other relationships, and it is highly likely that these relationships will affect each other (Cook \& Emerson, 1978). In the research reported here, we found that the breach of psychological contract between the supervisor and the organization had a trickle-down effect on the breach of the subordinate's psychological contract with the supervisor and the quality of customer service delivered by the subordinate. We also provided evidence for the mediating mechanisms that help explain the reason for the trickle-down effect. Consistent with social exchange theory, we found that perceptions of breach are accompanied by a reduction in discretionary effort by supervisors (OCBs toward the subordinate) and subordinates (OCBs toward the customer).

There has also been limited research on antecedents of breach. Based on the trickle-down model, we predicted that breach perceptions of the supervisor would be positively related to subordinate perceptions of breach. This prediction was supported. Thus, our results identified supervisor perceptions of breach as an antecedent to subordinate perceptions of breach with the supervisor (as well as with the organization, in Study 3). These results reinforce Ho's (2005) recommendation that psychological contract research pay greater attention to the effects of the social and network relationships in which employees are embedded.

Research to date has focused largely on employee perceptions of breach with the organization. We adopted a multifoci approach to breach and examined supervisor perceptions of breach with the organization and subordinate perceptions of breach with the supervisor. Psychological contract theory notes that even though the psychological contract may be between the employee and the organization, the promises on behalf of the organization are made by agents such as the supervisor (Rousseau, 1995, 1998). Therefore, it seems highly likely that in addition to the generalized expectations from the organization, employees will also have perceptions of obligations from the supervisor (Coyle-Shapiro \& Shore, 2007). Our results provide some support to this reasoning. The multifoci approach enabled the demonstration of the trickle-down effects. Future research should explore other foci in relation to psychological contracts, including coworkers and work teams (Marks, 2001). 
Path $\mathrm{C}$ in our model predicted that subordinate perceptions of PCB-S will be negatively related to subordinate OCBs toward the customer, and Path D predicted a positive relationship between subordinate OCBs toward the customer and customer satisfaction; both predictions were supported. Subordinate PCB-S was related to customer ratings of satisfaction with the service encounter, and this relationship was mediated by subordinate OCBs toward the customer. These finding contribute to the growing literature linking customer outcomes with the internal workings of the organization (Schneider et al., 2005). While a wide variety of outcomes of breach have been investigated (Zhao et al., 2007), to our knowledge customer service has not been associated with breach. More generally, existing research on breach focuses on employee outcomes but fails to extend the consequences for others in the employee's sphere of influence (e.g., coworkers, customers, family members; cf. Hoobler \& Brass, 2006). Our findings have shown that the detrimental consequences are not limited to individual attitudes and performance but affect subordinates and customers.

These findings also raise further questions about the nature of the trickle-down effect that need to be considered in future research. First, what are the underlying reasons and motivations for the supervisor's reduction in OCBs toward the subordinate? The supervisor, experiencing psychological contract breach by the organization, may not have the job resources that allow OCBs toward the subordinate. As noted by Cook and Emerson (1978), positive connections in social exchange networks involve situations where the exchange between $\mathrm{B}$ and $\mathrm{C}$ (e.g., the supervisor and the subordinate) is dependent on a prior exchange between $\mathrm{A}$ and B (e.g., the organization and the supervisor). Breach of the psychological contract by the organization may render the supervisor unable to provide the mentorship or support expected by the subordinate. On the other hand, withholding effort may arise from a wish to harm organizational interests. Bordia and his colleagues (2008) have demonstrated that psychological contract breach can result in an intention to seek revenge with the organization and direct deviant behaviors toward the organization as well as toward coworkers.

Second, what are the boundary conditions of trickle-down effects? Research on leadermember exchange (LMX) notes that supervisors do not treat all subordinates the same: Those with a high-LMX relationship get preferential treatment compared to those with a low-LMX relationship (Liden \& Graen, 1980). The low-LMX subordinate may be targeted for withdrawal of OCBs, while high-LMX subordinates may be protected. Thus, LMX may act as a moderator of the trickle-down effect of breach whereby the trickle-down effect is stronger for subordinates in low-LMX relationships with their supervisors (Coyle-Shapiro \& Shore, 2007). The studies reported here were conducted in the Philippines, a collectivist country where people emphasize smooth interpersonal relationships (Church, 1987). Will the findings generalize to other cultures? We are cautiously optimistic, given that the negative consequences of psychological contract breach have been identified in a range of countries and varying cultural contexts, including Australia (Winter \& Jackson, 2006), Belgium (De Vos, Buyens, \& Schalk, 2005), China (Hui, Lee, \& Rousseau, 2004), Israel (Krausz, 2000), Argentina (Dabos \& Rousseau, 2004), Pakistan (Raja et al., 2004), the United Kingdom (Coyle-Shapiro \& Conway, 2005), and the United States (Rousseau, 1995).

In addition to the theoretical contributions, the study had significant methodological strengths: To test the predictions, we obtained data from multiple sources, including supervisors, subordinates, customers, and organizational records. In Studies 1 and 2, data on customer 
satisfaction were obtained after gaps of 3 and 1 months, respectively, strengthening the causal implications of our findings. However, a major limitation of the current research is the cross-sectional nature of the design when collecting data on breach perceptions of supervisors and subordinates; this does not allow us to draw causal inferences. Future research should adopt a longitudinal design so as to be able to test the causal link between supervisor perceptions of breach and subordinate and customer outcomes.

\section{Practical Implications}

This study has demonstrated a negative link between employee perceptions of breach of psychological contract and customer satisfaction. Low levels of customer satisfaction can have major negative consequences for organizations. Dissatisfied customers are less likely to engage in repeat business with the organization and more likely to display negative word of mouth and complaining behavior (Szymanski \& Henard, 2001). Thus, organizations should strive to fulfill the psychological contract of employees with customer contact.

The trickle-down effect of supervisor PCB-O on subordinate and customer outcomes signifies that organizations should pay particular attention to the psychological contracts of key supervisors. The PCB-O of a supervisor in a high position in the vertical hierarchy of the organization would have implications for a large number of employees and customers, and a trickle could escalate into a flood of breaches. Schneider et al. (2005) noted that leader behaviors are instrumental in shaping an organization's climate. A repetitive and widespread pattern of breach, originating from the actions of the supervisor and trickling down the hierarchy, could become institutionalized as a "breach climate" and have devastating consequences for employee retention and organizational performance. To stop such widespread negative effects, organizations should be aware of their promised obligations to supervisory employees and attempt to fulfill their obligations. If breach does occur, organizations should provide an explanation and redress the loss of promised outcomes by other means (Rousseau, 1995). Supervisors should also be cautioned against targeting their frustration or disappointment toward their subordinates.

In conclusion, this research has drawn attention to the interconnected nature of employees' experiences and actions and their consequences. When seen in this light, breach seems even more damaging for employees, organizations, and customers. We hope that future research and applications of the construct of psychological contract breach will unravel further interconnections and develop ways to better manage mutual obligations between the exchange parties.

\section{Note}

1. We conducted two validation exercises to examine the construct validity of subordinate perceptions of psychological contract breach-supervisor (PCB-S) by collecting additional data from a sample of 158 full-time nonacademic university staff members from the Philippines. First, to assess construct distinctiveness, we measured PCB-S and supervisor perceptions of psychological contract breach-organization (PCB-O) using the same scales as the current study and leader-member exchange (LMX) using a seven-item scale from Graen and Uhl-Bien (1995). A confirmatory factor analysis of a three-factor model revealed a good fit, as indicated by the various fit indices 
(Model 1): $\chi^{2}(99, N=158)=191.35, p<.001, \chi^{2} / d f=1.93, \mathrm{CFI}=.95$, RMSEA $=.077$ (confidence interval 90\%: .061-.09). We also compared Model 1 with four alternative models; in each case, Model 1 had a better fit. Model 2 incorporated PCB-S and LMX into Factor 1 and PCB-O into Factor 2: Model 1 versus Model 2, $\chi_{\text {diff }}^{2}(1)=65.33$, $p<.001$. Model 3 combined PCB-S and PCB-O into Factor 1, and LMX into Factor 2: Model 1 versus Model 3, $\chi_{\text {diff }}^{2}(1)=6.32, p<.05$. Model 4 combined PCB-O and LMX into Factor 1, and PCB-S into Factor 2: Model 1 versus Model 4, $\chi_{\text {diff }}^{2}(1)=14.7, p<.001$. Finally, Model 5 incorporated all three constructs into one factor: Model 1 versus Model 5, $\chi_{\text {diff }}^{2}(1)=14.8, p<.001$. Second, we examined the incremental validity of PCB-S (Hunsley \& Meyer, 2003). That is, we tested whether PCB-S explained variance in work attitudes and behaviors over and above PCB-O and LMX. PCB-S contributed additional variance of $16 \%(p<.001)$ in trust toward supervisor, $2 \%(p<$ $.04)$ in turnover intentions, $3 \%(p<.05)$ in supervisor-rated job satisfaction, and $3 \%(p<.05)$ in supervisor-rated helping behavior, over and above the effects of PCB-O and LMX. Overall, the two validation exercises provide strong support for treating PCB-S as a distinct construct.

\section{References}

Aquino, K., \& Lamertz, K. 2004. A relational model of workplace victimization: Social roles and patterns of victimization in dyadic relationships. Journal of Applied Psychology, 89: 1023-1034.

Anderson, J. C., \& Gerbing, D. W. 1988. Structural equation modeling in practice: A review and recommended two-step approach. Psychological Bulletin, 103: 411-423.

Aryee, S., Budhwar, P. S., \& Chen, Z. X. 2002. Trust as a mediator of the relationship between organizational justice and work outcomes: Test of a social exchange model. Journal of Organizational Behavior, 2: 267-286.

Aryee, S., Chen, Z. X., Sun, L., \& Debrah, Y. A. 2007. Antecedents and outcomes of abusive supervision: Test of a trickle-down model. Journal of Applied Psychology, 9: 191-201.

Bernardo, A. B. I. 2004. McKinley's questionable bequest: Over 100 years of English in Philippine education. World Englishes, 2: 17-31.

Bettencourt, L. A., \& Brown, S. W. 1997. Contact employees: Relationships among workplace fairness, job satisfaction and prosocial service behaviors. Journal of Retailing, 73: 39-61.

Bludau, T. M., Herman, J. L., Williams, L. J., \& Cortina, J. M. 2007. Fit indices for evaluating latent variable models: A review of measurement, structural, and other components. Paper presented at the 22nd Annual Meeting of the Society for Industrial/Organizational Psychology, New York, NY.

Bordia, P., Restubog, S. L. D., \& Tang, R. L. 2008. When employees strike back: Investigating mediating mechanisms between psychological contract breach and workplace deviance. Journal of Applied Psychology, 93: 1104-1117.

Chen, Z. X., Tsui, A. S., \& Zhong, L. 2008. Reactions to psychological contract breach: A dual perspective. Journal of Organizational Behavior, 29: 527-548.

Church, A. T. 1987. Personality research in a non-Western culture: The Philippines. Psychological Bulletin, 102: 272-292.

Conway, N., \& Briner, R. B. 2005. Understanding psychological contracts at work: A critical evaluation of theory and research. Oxford, U.K.: Oxford University Press.

Conway, N., \& Briner, R. B. 2009. Fifty years of psychological contract research: What do we know and what are the main challenges? In G. P. Hodgkinson \& J. K. Ford (Eds.), International review of industrial and organizational psychology (vol. 24): 71-131. Chichester, UK: Wiley-Blackwell.

Cook, K. S., \& Emerson, R. M. 1978. Power, equity and commitment in exchange networks. American Sociological Review, 43: 721-739.

Coyle-Shapiro, J. A-M., \& Conway, N. 2004. The employment relationship through the lens of social exchange. In J. A-M. Coyle-Shapiro, L. M. Shore, M. S. Taylor, \& L. E. Tetrick (Eds.), The employment relationship: Examining psychological and contextual perspectives: 5-28. New York: Oxford University Press.

Coyle-Shapiro, J. A-M., \& Conway, N. 2005. Exchange relationships: Examining psychological contracts and perceived organizational support. Journal of Applied Psychology, 90: 774-781.

Coyle-Shapiro, J. A-M., \& Shore, L. M. 2007. The employee-organization relationship: Where do we go from here? Human Resource Management Review, 17: 166-179. 
Cronbach, L. J. 1951. Coefficient alpha and the internal structure of tests. Psychometrika, 16: 297-334.

Cropanzano, R., \& Rupp, D. E. 2008. Social exchange theory and organizational justice: Job performance, citizenship behaviors, multiple foci, and a historical integration of two literatures. In S. W. Gilliland, D. P. Skarlicki, \& D. D. Steiner (Eds.), Research in social issues in management: Justice, morality, and social responsibility: 63-99. Greenwich, CT: Information Age.

Dabos, G. E., \& Rousseau, D. M. 2004. Mutuality and reciprocity in the psychological contracts of employees and employers. Journal of Applied Psychology, 89: 52-72.

Deery, S. J., Iverson, R. D., \& Walsh, J. T. 2006. Toward a better understanding of psychological contract breach: A study of customer service employees. Journal of Applied Psychology, 91: 166-175.

Degoey, P. 2000. Contagious justice: Exploring the social construction of justice in organizations. Research in Organizational Behavior, 22: 51-102.

De Vos, A., Buyens, D., \& Schalk, R. 2005. Making sense of a new employment relationship: Psychological contract-related information seeking and the role of work values and locus of control. International Journal of Selection and Assessment, 13: 41-52.

Dulac, T., Coyle-Shapiro, J. A-M., Henderson, D. J., \& Wayne, S. J. 2008. Not all responses to breach are the same: The interconnection of social exchange and psychological contract processes in organizations. Academy of Management Journal, 51: 1079-1098.

Eisenberger, R., Stinglhamber, F., Vandenberghe, C., Sucharski, I. L., \& Rhoades, L. 2002. Perceived supervisor support: Contributions to perceived organizational support and employee retention. Journal of Applied Psychology, 87: $565-573$.

Emerson, R. 1976. Social exchange theory. Annual Review of Sociology, 2: 335-362.

Emerson, R. 1981. Social exchange theory. In M. Rosenberg \& R. H. Turner (Eds.), Social psychology: Sociological perspectives: 30-65. New York: Basic Books.

Graen, G. B., \& Uhl-Bien, M. 1995. Development of leader-member exchange (LMX) theory of leadership over 25 years: Applying a multi-level multi-domain perspective. Leadership Quarterly, 6: 219-247.

Ho, V. T. 2005. Social influence on evaluations of psychological contract fulfillment. Academy of Management Review, 30: 113-128.

Hodgkinson, G. P., \& Sadler-Smith, E. 2003. Complex or unitary? A critique and empirical reassessment of the Allinson-Hayes Cognitive Style Index. Journal of Occupational and Organizational Psychology, 76: 243-268.

Homburg, C., Koschate, N., \& Hoyer, W. D. 2005. Do satisfied customers really pay more? A study of the relationship between customer satisfaction and willingness to pay. Journal of Marketing, 69: 84-96.

Hoobler, J. M., \& Brass, D. J. 2006. Abusive supervision and family undermining as displaced aggression. Journal of Applied Psychology, 91: 1125-1133.

Hu, L.-T., \& Bentler P. M. 1999. Cutoff criteria for fit indexes in covariance structure analysis: Conventional criteria versus new alternatives. Structural Equation Modeling: A Multidisciplinary Journal, 6: 1-55.

Hui, C., Lee, C., \& Rousseau, D. M. 2004. Psychological contract and organizational citizenship behavior in China: Investigating generalizability and instrumentality. Journal of Applied Psychology, 89: 311-321.

Hunsley, J., \& Meyer, G. J. 2003. The incremental validity of psychological testing and assessment: Conceptual, methodological, and statistical issues. Psychological assessment, 15: 446-455.

Karriker, J. H., \& Williams, M. L. 2009. Organizational justice and organizational citizenship behavior: A mediated multifoci model. Journal of Management, 35: 112-135.

Katz, D., \& Kahn, R. L. 1978. The social psychology of organizations. New York: John Wiley.

Kline, R. B. 1998. Principles and practice of structural equation modeling. New York: Guilford.

Krausz, M. 2000. Psychological contracts in Israel. In D. M. Rousseau \& R. Schalk (Eds.). Psychological contracts in employment: Cross-national perspectives: 125-140. Thousand Oaks, CA: Sage.

Lavelle, J. J., Rupp, D. E., \& Brockner, J. 2007. Taking a multifoci approach to the study of justice, social exchange, and citizenship behavior: The target similarity model. Journal of Management, 33: 841-866.

LeBreton, J. M., Wu, J., \& Bing, M. N. 2009. The truth(s) on testing for mediation in the social and organizational sciences. In C. E. Lance \& R. J. Vandenberg (Eds.), Statistical and methodological myths and urban legends: Doctrine, verity and fable in the organizational and social sciences: 107-141. New York: Routledge.

Liden, R. C., \& Graen, G. 1980. Generalizability of the vertical dyad linkage model of leadership. Academy of Management Journal, 23: 451-465. 
Little, T. D., Cunningham, W. A., Shahar, G., \& Widaman, K. F. 2002. To parcel or not to parcel: Exploring the question, weighing the merits. Structural Equation Modeling, 9: 151-173.

MacKinnon, D. P., Fritz, M. S., Williams, J., \& Lockwood, C. M. 2007. Distribution of the product confidence limits for the indirect effect: Program PRODCLIN. Behavior Research Methods, 39: 384-389.

Marcus-Newhall, A., Pedersen, W., Carlson, M., \& Miller, N. 2000. Displaced aggression is alive and well: A metaanalytic review. Journal of Personality and Social Psychology, 78: 670-689.

Marks, A. 2001. Developing a multiple foci conceptualization of the psychological contract. Employee Relations, 23: 454-467.

Masterson, S. S. 2001. A trickle-down model of organizational justice: Relating employees' and customers' perceptions of and reactions to fairness. Journal of Applied Psychology, 86: 594-604.

Mathieu, J. E., Tannenbaum, S. I., \& Salas, E. 1992. Influences of individual and situational characteristics on measures of training effectiveness. Academy of Management Journal, 35: 828-847.

Morrison, E. W., \& Robinson, S. L. 1997. When employees feel betrayed: A model how psychological contract develops. Academy of Management Review, 22: 226-256.

Nunnally, J. C. 1978. Psychometric theory. New York: McGraw-Hill.

Podsakoff, P. M., MacKenzie, S. B., Paine, J. B., \& Bachrach, D. G. 2000. Organizational citizenship behaviors: A critical review of the theoretical and empirical literature and suggestions for future research. Journal of Management, 26: 513-563.

Ragins, B. R., \& McFarlin, D. B. 1990. Perceptions of mentor roles in cross-gender mentoring relationships. Journal of Vocational Behavior, 37: 321-329.

Raja, U., Johns, G., \& Ntalianis, F. 2004. The impact of personality on psychological contracts. Academy of Management Journal, 47: 350-367.

Restubog, S. L. D., Bordia, P., \& Tang, R. L. 2006. Effects of psychological contract breach on performance of IT employees: The mediating role of affective commitment. Journal of Occupational and Organizational Psychology, 79: 299-306.

Restubog, S. L. D., Hornsey, M., Bordia, P., \& Esposo, S. 2008. Effects of psychological contract breach on organizational citizenship behaviour: Insights from the group value model. Journal of Management Studies, 45: 1377-1400.

Robinson, S. L., \& Morrison, E. W. 2000. The development of psychological contract breach and violation: A longitudinal study. Journal of Organizational Behavior, 21: 525-546.

Robinson, S. L., \& Rousseau, D. M. 1994. Violating the psychological contract: Not the exception but the norm. Journal of Organizational Behavior, 15: 245-259.

Rousseau, D. M. 1995. Psychological contracts in organizations: Understanding written and unwritten agreements. Thousand Oaks, CA: Sage.

Rousseau, D. M. 1998. The "problem" of psychological contract considered. Journal of Organizational Behavior, 19: 665-671.

Rousseau, D. M., \& Greller, M. M. 1994. Human resource practices: Administrative contract makers. Human Resource Management, 33: 384-401.

Rupp, D. E., \& Cropanzano, R. 2002. The mediating effects of social exchange relationships in predicting workplace outcomes from multifoci organizational justice. Organizational Behavior and Human Decision Processes, 89: 925-946.

Schneider, B., Ehrhart, M. G., Mayer, D. M., Saltz, J. L., \& Niles-Jolly, K. 2005. Understanding organizationcustomer links in service settings. Academy of Management Journal, 48: 1017-1032.

Schneider, B., Gunnarson, S. K., \& Niles-Jolly, K. 1994. Creating the climate and culture of success. Organizational Dynamics, 23: 17-29.

Shanock, L. R., \& Eisenberger, R. 2006. When supervisors feel supported: Relationships with subordinates' perceived supervisor support, perceived organizational support, and performance. Journal of Applied Psychology, 91: 689-695.

Shore, L. M., \& Tetrick, L. E. 1994. The psychological contract as an explanatory framework in the employment relationship. In C. L. Cooper \& D. M. Rousseau (Eds.), Trends in organizational behavior: 91-103. New York: John Wiley.

Shore, L. M., Tetrick, L. E., Taylor, S. M., Coyle-Shapiro, A-M., Liden, R. C., McLean Parks, J., Morrison, E. W., Lyman, W. P., Robinson, S. L., Roehling, M. V., Rousseau, D. M., Schalk, R., Tsui, A. S., \& Van Dyne, L. 2004. 
The employee-organization relationship: A timely concept in a period of transition. Research in Personnel and Human Resource Management, 23: 291-370.

Sobel, M. E. 1982. Asymptotic confidence intervals for indirect effects in structural equation models. Sociological Methodology, 13: 290-312.

Steiger, J. H. 1980. Tests for comparing elements of a correlation matrix. Psychological Bulletin, 87: $235-251$.

Stinglhamber, F., \& Vandenberghe, C. 2003. Organizations and supervisors as sources of support and targets of commitment: A longitudinal study. Journal of Organizational Behavior, 24: 251-270.

Szymanski, D. M., \& Henard, D. H. 2001. Customer satisfaction: A meta-analysis of the empirical evidence. Journal of the Academy of Marketing Science, 29: 16-35.

Tanaka, J. S. 1993. Multifaceted conceptions of fit in structural equation models. In K. A. Bollen \& J. S. Long (Eds.), Testing structural equation models: 10-39. Newbury Park, CA: Sage.

Taylor, M. S., \& Tekleab, A. G. 2004. Taking stock of psychological contract research: Assessing progress, addressing troublesome issues, and setting research priorities. In J. A-M. Coyle-Shapiro, L. M. Shore, M. S. Taylor, \& L. E. Tetrick (Eds.), The employment relationship: Examining psychological and contextual perspectives: 253-283. New York: Oxford University Press.

Tekleab, A. G., \& Taylor, M. S. 2003. Aren’t there two parties in an employment relationship? Antecedents and consequences of organization-employee agreement on contract obligations and violations. Journal of Organizational Behavior, 24: 585-608.

Tepper, B. J., \& Taylor, E. C. 2003. Relationships among supervisors' and subordinates' procedural justice perceptions and organizational citizenship behaviors. Academy of Management Journal, 46: 96-105.

Tsiros, M., Mittal, V., \& Ross, W. T., Jr. 2004. The role of attributions in customer satisfaction: A re-examination. Journal of Consumer Research, 31: 476-483.

Turnley, W. H., Bolino, M. C., Lester, S. W., \& Bloodgood, J. M. 2003. The impact of psychological contract fulfillment on the performance of in-role and organizational citizenship behaviors. Journal of Management, 29: 187-206.

Whetten, D. A. 1989. What constitutes a theoretical contribution? Academy of Management Review, 14: 490-495.

Williams, L. J., Vandenberg, R. J., \& Edwards, J. R. 2009. Structural equation modeling in management research: A guide for improved analysis. Academy of Management Annals, 3: 543-604.

Winter, R. P., \& Jackson, B. 2006. State of the psychological contract: Manager and employee perspectives within an Australian credit union. Employee Relations, 28: 421-434.

Yeung, A. K., \& Berman, B. 1997. Adding value through human resources: Reorienting human resource measurement to drive business performance. Human Resource Management, 36: 321-335.

Zhao, H., Wayne, S. J., Glibkowski, B. C., \& Bravo, J. 2007. The impact of psychological contract breach on workrelated outcomes: A meta-analysis. Personnel Psychology, 60: 647-680. 